\title{
Canadian Political Science and Medicare: Six Decades of Inquiry
}

\section{Science politique et assurance maladie au Canada : soixante ans d'enquête}

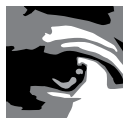 \\ MICHAEL A. O'NEILL, PHD \\ Institute on Governance \\ Ottawa, ON \\ DYLAN MCGUINTY, BA, MA \\ Department of Philosophy, Faculty of Arts \\ University of Ottawa \\ Ottawa, ON \\ BRYAN TESKEY, BA \\ Common Law Section, Faculty of Law \\ University of Ottawa \\ Ottawa, ON
}

\begin{abstract}
Based on an extensive sample of the literature, this critical review dissects the principal themes that have animated the Canadian political science profession on the topic of medicare. The review considers the coincidence of economic eras and how these are reflected in the methodological approaches to the study of medicare. As is to be expected, most of the scholarly activity coincides with the economic era marked by fiscal restraint and decreases in social investments (1993-2003). At the same time, the review notes the prevalence of institutionalism as an approach to the topic and the scholarly community's near-consensus on medicare as a defining characteristic of the country and its people.
\end{abstract}




\section{Résumé}

Cette revue critique, fondée sur un vaste échantillon de la littérature, examine les principaux thèmes qui ont stimulé la science politique au Canada en matière d'assurance maladie. La revue tient compte de la coïncidence des périodes économiques et de la façon dont elles sont reflétées dans les démarches méthodologiques pour l'étude de l'assurance maladie. Tel que pressenti, la plupart des activités des chercheurs coïncident avec la période économique marquée par les restrictions budgétaires et les coupures dans l'investissement social (1993-2003). Parallèlement, la revue indique la prévalence de l'institutionnalisme comme démarche adoptée pour ce sujet. Elle indique également la présence d'un quasi consensus du milieu de la recherche, lequel voit l'assurance maladie comme une caractéristique qui définit le pays et ses habitants.

\section{There are few issues of more concern to Canadians than the state of their public healthcare system, or medicare. As Soroka (2007:5) notes in a recent and comprehensive study of Canadian public opinion on this topic: "for many} Canadians, publicly funded universal health care is one of the foremost policy features of the Canadian state." Some analysts have gone further and argued that this attachment is so strong that it deflects attempts to downsize or significantly alter the shape and scope of medicare (O'Neill 1996). Although medicare is an issue with high political salience, there has been limited work in the social sciences to define health policy studies (see Abelson et al. 2008), and no one has attempted a holistic view of the political science profession's contribution to the study of medicare per se.

This paper provides an overview of the content of peer-reviewed papers written by Canadian political scientists on the topic of medicare. The conclusions drawn as a result of this literature review will highlight the preferences of the discipline in terms of its research methodology and approaches to the study of medicare. At the same time, it points to some of the salient issues raised in the literature over the six decades of inquiry we have considered. Some of our findings may be intuitive to students of Canadian politics, such as the profession's preference for normative research as opposed to theory and modelling. However, we also propose newer findings, such as the prevalence of institutionalism over these six decades, which may shed further light on the general scholarship of the Canadian discipline. In undertaking this literature review, we find inspiration in Richard Simeon's (2002) previous work and the conclusions he drew about the Canadian academy.

This paper contributes principally to the field of political science, although we believe it will be of interest to scholars from other fields who share an interest in medicare or health insurance systems in general. If we accept that medicare is "a touchstone of [Canadian] citizen identification" (Boychuk 2008: 141) and that the interests of the academy and the public (including the elite public) should coincide, then we should see evidence of this in the published output of the Canadian political science profession. 
This paper will also be of interest to health policy analysts and others directly involved in the development and management of Canada's health insurance system. The paper achieves this by informing the discussion about medicare through the prism of a social science that studies governments, public policies, political processes and systems, and political behaviour. We believe that a better understanding of these forces and actors can assist in developing public policy tools, in the analysis of past public policy decisions and in lesson drawing to aid future policy development.

\section{Medicare-related articles by Canadian political scientists: 1946-2006}

Much of the Canadian academic literature on medicare has leaned heavily towards the economic approach. Typical of this is Robert G. Evans, who has written over 40 books and many more papers on the subject of medicare. However, as political scientists, our interest lay in the research output of our peers. To do so, we chose to focus on the research output of the Canadian community of political scientists between 1946 and 2006 through a comparative and content analysis of the papers published in Canadian and specialty health politics journals. In doing so, we acknowledge that our discussion concerning the final period we examined (2003-2006) is limited given that it considers only three years of scholarly activity and, therefore, cannot be fully compared to preceding periods that are much longer.

The decision to concentrate only on peer-reviewed papers rather than books was not without consequence; by focusing on papers, we were able to include a large number of writings by Canadian political scientists in our analysis and review. The representativeness of these papers was confirmed through a review of scholarly citation indexes and research library catalogues. We accept, however, that this approach is not without limitations, for it also meant that seminal books on the topic of medicare were not captured in this review. However, this limitation is largely mitigated by the inclusion of papers that reflect the writings of political scientists in other forms, such as we propose is the case for Malcolm Taylor (1960, 1972, 2009). Furthermore, we believe that choosing to focus on papers is consistent with our purpose of painting a picture of a scholarly field's contribution on medicare.

The criteria applied to select the papers, though imperfect, allowed us to focus on a significant segment of the Canadian political science profession. For the purposes of this review, institutional affiliation was used as a proxy for nationality. While we recognize that this eliminates papers written by Canadians in institutions outside Canada (and includes nonCanadians researching in Canadian institutions), on the whole we contend that this approach provides a more catholic understanding of the community of scholars whose work we were interested in studying. Moreover, taking inspiration from Cameron and Krikorian (2002), we contend that as the papers selected for review were published in leading Canadian and health politics and policy journals, these reflect the dominant trends and patterns in the Canadian discipline over the period under review.

Second, we opted not to overly subdivide the profession. In this study, political science is broadly defined and includes the field of public administration. Note that we purposely 
excluded from the analysis studies made by non-political scientists that use the methods of political science (or were published in policy or public administration journals). This is not to negate the important contribution made by these fields, but merely to circumscribe the analysis to the core research unit (Canadian political scientists).

Relying on a combination of keywords (e.g., Canada, medicare, health insurance) and the criteria noted above, commercial databases (JSTOR, PAIS, Social Sciences Abstracts and Sage's Political Science) were used to find the papers. This approach elicited a list of 44 papers, which we further pared down using citation indexes in order to focus on the papers with the greatest impact within the discipline. Twenty-seven papers were retained as exemplars of Canadian scholarship on the topic of medicare, and these are the object of the analysis reported below.

In undertaking this review, our objectives were twofold: first, to determine whether and why scholarly attention to medicare ebbed and flowed over time. Second, after Simeon (2002), we were interested in finding out whether one school or approach was dominant in the study of medicare or whether a number of approaches competed in the discipline.

In undertaking our analysis we drew upon Howlett and Ramesh (2003) and Simeon (2002). Howlett and Ramesh inspired the method of analysis that considered different possible combinations of units, method and levels of analysis. Simeon inspired a review that considered the three dominant models that have marked Canadian political science: political culture, political economy and institutionalism (Simeon 2002: 32-39).

\section{Six Decades of Inquiry}

The Canadian welfare state, and medicare in particular, did not develop in isolation from the broader economic and social contexts. This view is admirably captured in the title of Malcolm Taylor's classic 1978 study (Taylor 2009). Recognizing this, we grouped the papers we reviewed according to economic and social eras. These eras are understood to mean periods marked by (1) policies aimed at regulating or deregulating the competitive market economy and fiscal policy and (2) the normative theory about the role of government, evidenced by regulatory and fiscal policies. We have chosen to tie the elements of the social scientific theories of the reviewed texts into the "eras" of Canadian economic and social policy, not necessarily to show some causal effect between the two, but to stir discussion about the possibility of causality or correlation between economic policy eras and the ways in which academics have studied health policy.

Drawing principally on the work of Geoffrey Hale (2002) and others (O'Neill 1997; Rice and Prince 2000; Marchildon 2006; Lazar et al. 2004; Maioni 2002), we divided the periods marking the key development of medicare into five economic eras:

- 1945-1967: Post-Second World War Keynesianism and the expansion of the welfare state

+ 1968-1983: Market regulation, expansion of the welfare state and deficit spending

- 1984-1992: Deregulation, privatization, commercialization and deficit spending

+ 1993-2003: Fiscal restraint and decrease in health and social spending

+ 2004-2006: Beginning of reinvestment in health and social spending 
Of note, given the time lag between paper submission and publication date, we used a measure of discretion by including a paper within the era of inclusion that we deemed most relevant.

\section{5-1967: Post-Second World War Keynesianism and the expansion of the welfare state} In Canada and elsewhere, the post-war period saw the emergence of a broad social consensus in favour of a new economic and social model for the nation (Lightman 2003: 4). In policy terms, the consensus was concretized with the establishment of the Canadian welfare state, of which medicare was a cornerstone (Rice and Prince 2000: 232-40).

The papers published during this period mark the first forays by the political science profession into the topic of medicare. Those published in the era introduce an interest in institutions and interest groups as the primary unit of analysis that would become perennial in the output of the profession over the 60 years that followed. Between 1946 and 1960, three notable papers were published: Taylor (1960), writing in the pluralist vein, examined the role of the medical profession in health insurance decision-making, whereas Gelber (1966) explored the institutional dimension of establishing a health insurance system. However, Gray's (1946) paper, in the Canadian Journal of Economics and Political Science, was the first to signal the profession's interest in the politics of health insurance with a Canada-US study of the forces that influenced the development and shape of public health insurance plans. This approach would introduce into the profession not only a new topic of inquiry but also establish a frequently emulated focus on institutions and interest groups. In this sense, Taylor (1960) and Gelber (1966) are both heirs to Gray's original study. Looking forward, we see a lineage between these early papers on medicare and the later ones, such as Howlett (2002), Geva-May and Maslove (2000) and Tuohy (1988).

\section{8-1983: Market regulation, expansion of the welfare state and deficit spending}

The years immediately following Canada's centennial were marked by the continued development and expansion of the Canadian welfare state. By 1972, all provinces had concluded agreements with Ottawa for the establishment of medicare (Rice and Prince 2000: 70). Yet, within five years of this landmark year, the Canadian welfare state would experience a contraction. Up to this point, political constraints on the growth of social spending were few, but the conjunction of a global economic slowdown and the steady growth of the federal government's budget deficit and apprehended fiscal policy crisis caused a political and economic challenge to the Canadian welfare state (Hale 2002: 150-51). Thus, if the start of this second economic era was marked by the expansion of social entitlements, it ended with the first frontal attacks on the edifice of the post-war Keynesian consensus and the dampening of the commitment to the fiscal underpinning of the welfare state and medicare (Marchildon 2006: 7).

The shifting political and economic tides are not reflected in the output of the profession during this period. The focus of the studies continued to be on the founding actors and decision-making models that had marked the establishment of medicare and the Canadian welfare state. Thus, Taylor (1972) reprises his earlier interest in the role played by the medical 
profession and the clash of this entrenched interest with the policy makers of the day. This was also the theme of Tuohy's (1976) paper. Only Rivest's (1984) paper is notable because of its focus on the state and his interest in the factors that contributed to the development of the welfare state in Canada. Published at a time when Canada was in the midst of an economic downturn, Rivest's paper introduces themes that reflected the changing political and societal attitude towards the welfare state. His concern with the raison d'être of the state's role in medicare served as a challenge to those who promoted disengagement. In this way, Rivest marks both the end of the second economic era while introducing themes that would be germane in the economic era to follow.

\section{4-1992: Deregulation, privatization, commercialization and deficit spending}

Nineteen eighty-four marked the start of a new economic and social policy era, as well as a new political era, with the election in September of the Progressive Conservative Party. Led by Brian Mulroney, Canada joined the United Kingdom and the United States in having conservative governments, although Mulroney's paled in comparison to the latter in its adherence to neo-liberalism. For example, while the Conservatives were the Official Opposition, they supported the passage of the Canada Health Act - a landmark piece of legislation that consolidated medicare as a touchstone social policy. Looking back on the two Mulroney governments, it is evident that economic policy outweighed social policy as a priority (Hale 2002: 181). Overall, medicare emerged virtually intact after the Mulroney government (O'Neill 1996).

The papers published in this third economic era break down almost equally between the institutionalist and pluralist approaches. Barker (1989), Mhatre and Deber (1992) and, to a lesser extent, Lemieux (1989) typify the institutional approach, with studies focusing on public inquiries and decision-making within the governmental machinery. Fulton and Stanbury (1985) and Tuohy (1988) reprise a familiar theme in the literature by focusing on the arbitrage and influence role played by the medical profession in medicare decision-making. It could be said that the contributions of this era attempt to explain governmental decision-making using different lenses.

However, this era is notable in that the public tumult over the future of medicare percolated into the academy and, we propose, may explain the notable increase in the number of papers by Canadian political scientists written in the following decade.

\section{3-2003: Fiscal restraint and decrease in health and social spending}

The return of the Liberal Party to federal office marked the second major retrenchment in the funding of medicare. Faced with unprecedented fiscal and exogenous pressures from the international financial community, the new Chrétien government borrowed from the neoliberal economic policy playbook to bring the federal budget deficit under control through reductions in federal program spending (Hale 2002: 225). For medicare, the fiscal "horse medicine" imposed by finance minister Paul Martin resulted in the amputation of the federal government's share of medicare funding and a rate of increase set below GDP growth (Lazar 
et al. 2004: 193). Coupled with the efforts of provincial finance ministers to address their own budgetary deficits (now made worse by federal actions), the future viability of medicare was increasingly at issue.

This fourth economic era is the one that saw the most activity in terms of the profession's output, possibly a delayed echo of the events of the previous economic era. The themes that emerge in the literature during this era concern the politics of retrenchment and the consequences of fiscal restraint in social policy. For example, Philipon and Wasylyshyn (1996) see a new fiscal paradigm as the principal motivation behind health reforms in Alberta, while Maioni (1998) uses this dimension to explore the diverging policy paths of the United States and Canada. In a study that considered the broader social policy field, Bashevkin (2000) returns to the theme of divergence between the Canadian and American policies. Given the interest of American political scientists for Canada's medicare, it is notable that Maioni and Bashevkin were the first to consider the Canada-US comparative set since Gray's 1946 paper.

This era also saw the publication of papers focused on particular dimensions of the healthcare debate - moving away from a strict focus on the politics of medicare to a broader consideration of health politics. Typical of this approach are Orsini's (2002) paper on the emergence of cause activism in Canada and Prince's (2001) discussion of federalism and the politics of disability. Both papers highlight a return to the traditional focus on both institutionalism and pluralism.

\section{4-2006: Beginning of reinvestment in bealth and social spending}

The final economic era studied is possibly too short to make any definitive inferences on the profession's output. In these three years, several changes in government at the federal and provincial levels (including three back-to-back minority governments at the federal level) have occurred, and the long-term consequences of the 2008-2009 global financial crisis are still unknown. The initial trend line, as drawn by the last years of the Liberal Party in federal office, point towards a reinvestment in medicare and the social welfare state generally (Lazar et al. 2004: 207). At time of writing, the Conservative Party - in office federally since 2006 - has not steered away from this course.

Although we eschew any broad generalizations given the limited literature published during this period, we do note a concern by members of the discipline with the politics of healthcare financing and medicare reform (St-Hilaire and Lazar 2003; Abelson et al. 2004; Davidson 2004; Church and Smith 2006). St-Hilaire and Lazar (2003) are principally concerned with intergovernmental discussions on medicare funding, while Davidson (2004) and Abelson and colleagues (2004) are concerned with policy trends, the former focusing on governments as the unit of analysis and Canadian public attitudes. All three papers are firmly anchored in the institutional approach. Church and Smith (2006), for their part, resort to a more traditional pluralist approach to explain developments in Alberta. At a very early stage in an economic era that has yet to be truly defined, we see a literature still articulating the issues in terms of developments branded in a period of restraint. 


\section{Discussion}

As Table 1 shows, the majority of Canadian scholarly interest on the topic of medicare coincides with the two periods marked by retrenchment (1984-1992 and 1993-2003). During these periods, two analytical trends emerge: the relative balance between the use of deductive and inductive methodologies, and the use of institutions as the principal units of analysis. The balance between papers written deductively and inductively is an indication of Canadian political scientists' ability to utilize both induction to come up with ideas or theories, and deduction to validate ideas. Ultimately, neither method is intrinsically preferable to the other.

TABLE 1. Six decades of inquiry into Canadian medicare

\begin{tabular}{|c|c|c|c|c|c|}
\hline & $\begin{array}{l}\text { Post-WWII } \\
\text { Keynesianism } \\
\text { and } \\
\text { expansion of } \\
\text { the welfare } \\
\text { state } \\
\text { I945-I967 }\end{array}$ & $\begin{array}{l}\text { Market } \\
\text { regulation, } \\
\text { expansion of } \\
\text { the welfare } \\
\text { state and } \\
\text { deficit } \\
\text { spending } \\
\text { 1968-|983 }\end{array}$ & $\begin{array}{l}\text { Deregulation, } \\
\text { privatization, } \\
\text { commercialization } \\
\text { and deficit } \\
\text { spending } \\
\text { |984-|992 }\end{array}$ & $\begin{array}{l}\text { Fiscal restraint } \\
\text { and decrease } \\
\text { in health and } \\
\text { social spending } \\
\text { 1993-2003 }\end{array}$ & $\begin{array}{l}\text { Beginning of } \\
\text { reinvestment } \\
\text { in health } \\
\text { and social } \\
\text { spending } \\
2004-2006\end{array}$ \\
\hline $\begin{array}{l}\text { Unit of Analysis: } \\
\text { Structures; } \\
\text { Method of } \\
\text { Analysis: } \\
\text { Inductive }\end{array}$ & Taylor (1960) & & $\begin{array}{l}\text { Barker (1989), } \\
\text { Lemieux (1989) }\end{array}$ & & \\
\hline $\begin{array}{l}\text { Unit of Analysis: } \\
\text { Structures; } \\
\text { Method of } \\
\text { Analysis: } \\
\text { Deductive }\end{array}$ & & Taylor ( 1972$)$ & Swartz (1993) & Howlett (2002) & \\
\hline $\begin{array}{l}\text { Unit of Analysis: } \\
\text { Institutions; } \\
\text { Method of } \\
\text { Analysis: } \\
\text { Inductive }\end{array}$ & $\begin{array}{l}\text { Gray (1946), } \\
\text { Gelber (1966) }\end{array}$ & & $\begin{array}{c}\text { Barker (1989), } \\
\text { Mhatre \& Deber } \\
\text { (1992) }\end{array}$ & $\begin{array}{c}\text { Philipon \& } \\
\text { Wasylyshyn } \\
\text { (1996), Maioni } \\
\text { (1998), Wilson } \\
\text { (200I), Kelly } \\
\text { (200I), St-Hilaire } \\
\text { \& Lazar (2003) }\end{array}$ & \\
\hline $\begin{array}{l}\text { Unit of Analysis: } \\
\text { Institutions; } \\
\text { Method of } \\
\text { Analysis: } \\
\text { Deductive }\end{array}$ & & $\begin{array}{l}\text { Taylor ( } 1972), \\
\text { Tuohy (1976), } \\
\text { Rivest (1984) }\end{array}$ & & $\begin{array}{c}\text { Bashevkin (2000), } \\
\text { Geva-May \& } \\
\text { Maslove (2000), } \\
\text { Prince (200I) }\end{array}$ & $\begin{array}{c}\text { Davidson } \\
\text { (2004), Church } \\
\text { \& Smith (2006) }\end{array}$ \\
\hline $\begin{array}{l}\text { Unit of Analysis: } \\
\text { Groups; } \\
\text { Method of } \\
\text { Analysis: } \\
\text { Inductive }\end{array}$ & Taylor (1960) & & & & \\
\hline
\end{tabular}


TABLE 1. Continued

\begin{tabular}{|l|l|l|l|l|l|}
\hline $\begin{array}{l}\text { Unit of Analysis: } \\
\text { Groups; } \\
\text { Method of } \\
\begin{array}{l}\text { Analysis: } \\
\text { Deductive }\end{array}\end{array}$ & $\begin{array}{c}\text { Taylor (1972), } \\
\text { Tuohy (1976) }\end{array}$ & $\begin{array}{c}\text { Fulton \& Stanbury } \\
\text { (1985), Tuohy (1988) }\end{array}$ & $\begin{array}{c}\text { Prince (2001), } \\
\text { Orsini (2002) }\end{array}$ & \\
\hline $\begin{array}{l}\text { Unit of Analysis: } \\
\text { Individuals; } \\
\text { Method of } \\
\text { Analysis: } \\
\text { Inductive }\end{array}$ & & & & Redden (2002) & $\begin{array}{c}\text { Abelson et al. } \\
\text { (2004) }\end{array}$ \\
\hline $\begin{array}{l}\text { Unit of Analysis: } \\
\text { Individuals; } \\
\text { Method of }\end{array}$ & & & & & \\
Analysis: & & & & & \\
Deductive & & & & & \\
\hline
\end{tabular}

If the methodological approach tended towards a relative balance between induction and deduction, we find a very strong disposition in the Canadian profession for writing on medicare from an institutionalist perspective. As Table 1 shows, the vast majority of papers rely on this framework. Papers written from an institutionalist perspective were more prevalent during periods when political and bureaucratic institutions seemed to hold greater sway over charting the future of medicare. By contrast, pluralist writings, those concerned principally with the influence of interest groups, were less prevalent between 1984 and 2003, a period that was marked by the increased influence of international financial institutions over social policy directions. If the academy reflects the political, economic and social context of the period, then it follows that a period marked by numerous public inquiries and commissions would also demonstrate an institutionalist bent (see Ham 2001). Also typical of the dominance of institutionalism is the concern with medicare's history and contemporary challenges, as opposed to the correlation between medicare and affected groups and individuals.

Given the fact that political scientists during the 1993 to 2003 period focused primarily on institutions rather than interest groups, we might conclude that the health policy making (formulation) process is of greater interest to scholars because institutions are the prime makers of health policy. The choice to study formulation can be attributed to the fact that this activity determines the substance of health policy. Thus, the consideration of procedure and substance may be complementary; policy formulation, which is characteristically "procedural," determines the substance - the final, singular aims and essential attributes of health policy.

In this manner, we subscribed to Sinclair's (1981) assertion that we can differentiate principle from action. In the papers we reviewed, we can see this in the focus on either the principles inherent in medicare policy making or in the actions taken by political actors. Policy change is more a political than an epistemological process, and policy debates focus on tools rather than aims (Davidson 2004: 253). This is true also in the case of medicare. 


\section{Observations}

The preceding literature review sought to determine, through processes of internal (methodology and framework) and external (temporal) classification, the contribution made by Canada's political scientists to the study of medicare. From the outset, we were conscious of the project's limitations. Some were discussed previously in terms of the study selection methodology. Are there other ways of measuring the contribution of academicians to public policy debate? The answer must be affirmative. For example, 11 of the 40 research reports commissioned by Canada's Commission on the Future of Health Care (the Romanow Commission) were authored by political scientists (see Forest et al. 2004). This would point to a high degree of contribution by Canadian political scientists to this area of public policy.

Is it possible to arrive at a concise and generalizable perspective on the contribution of Canadian political science to the study of medicare? Can we agree with Richard Simeon's proposition that "what is true of Canada generally is, of course, more so for those who study its politics" (2002: $\mathrm{x}$ ) by looking at Canadian political scientists' scholarly contributions to the topic? We answer in the affirmative to both questions and put forth the following proposition: The Canadian profession's principal contribution to the study and debate about medicare was to clarify the institutional dimensions that frame decision-making. Institutionalism, particularly the focus on the interactions between government and administrative institutions and dominant or influential social interests, has been a pre-eminent approach in the Canadian political science outlook on medicare. It is also exercised indirectly, where clarity around institutions enhances debate on medicare among the profession, but also in other fields of study, for example, health economics or law.

Our review was unable to determine whether the discipline's scholarly attention contributed to the public debate on medicare. Any observations in this regard would have required the inclusion of a far broader sample of publications - journalistic and similar. However, we can agree with Simeon's (2002: $\mathrm{x}$ ) previously cited proposal: Canadian political scientists are indeed members of society whose work mirrors the preoccupations of the broader public. Over six decades, the discipline's scholarly output mirrored the economic or social circumstances of the time. For example, the high incidence of papers written between 1993 and 2003 coincides with the period when the federal government was cutting investments in social and health policy, most notably through the creation of the Canada Health and Social Transfer. If this attribution of cause is correct, then, assuming that scholarly research objectives are moved by values, beliefs and concerns and are not arbitrarily chosen, it might be the case that academic interest in medicare is motivated by the same factors of public attachment to medicare that Boychuk (2008) and others have identified.

While we found a consistent interest in the topic of medicare among Canadian political scientists, we noted that the vast majority of the papers were published in English. Although we made specific efforts to ensure that French-language contributions were included in the study, few were found. This is not to state that the Québécois profession is uninterested in the topic. Among the papers considered in this study, Forest and colleagues (2004), Abelson 
and colleagues (2004), Maioni (1998), Lemieux (1989) and Rivest (1984) made contributions to scholarship on medicare at critical points in and around the public debate on its evolution. However, the number of scholarly papers found was comparatively small. This finding can be explained in part by our decision to focus on Canadian or health policy journals; the Quebecbased profession may be publishing in non-Canadian journals or journals not explicitly devoted to the study of health politics and policy, as is the case with Maioni's (1998) paper.

Finally, when looking at the output of the profession over 60 years, we note the primacy of normative inquiry over theoretical modelling. Although we cannot generalize from this limited study on the preferences of the entire discipline, perhaps medicare provides fertile ground for deductive inquiry.

\section{Conclusion}

If the political science profession showed itself an able communicator on the institutional constructs that affect decision-making, and if scholarly output was indeed in response to broad economic and social conditions at play, we found few examples where the literature was used as a pulpit for commentary or proposals for reform. This is not to say that there are no such cases. Swartz (1993) and Boase (2003), for example, ably mix commentary with analysis. And while all things must balance, we note that this lack of normative pronouncements may limit the impact of Canadian political scientists' overall contribution to the debate on medicare though perhaps this is an issue for another forum.

\section{ACKNOWLEDGEMENTS}

The authors wish to acknowledge Antonia Maioni, Michael Orsini and the journal's reviewers for their helpful comments and suggestions on a previous version of this paper. We also acknowledge the assistance of Alison Smith in preparing the final submission.

Correspondence may be directed to: Michael A. O’Neill, Director, Institute on Governance, 60 George Street, Suite 203, Ottawa ON K1N 1J4; e-mail: moneill@iog.ca.

\section{REFERENCES}

Abelson, J., M. Giacomini, J. Lavis and J. Eyles. 2008. Field of Dreams: Strengthening Health Policy Scholarship in Canada. Centre for Health Economics and Policy Analysis Working Paper 08-06. Hamilton, ON: McMaster University. Retrieved March 20, 2011. < http://ideas.repec.org/p/hpa/wpaper/200806.html>.

Abelson, J., M. Mendelsohn, J.N. Lavis, S.G. Morgan, P-G. Forest and M. Swinton. 2004. “Canadians Confront Health Care Reform." Health Affairs 23: 186-93.

Barker, P. 1989. “The Canada Health Act and the Cabinet Decision-Making System of Pierre Elliott Trudeau." Canadian Public Administration 32: 84-103.

Bashevkin, S. 2000. "Rethinking Retrenchment: North American Social Policy During the Early Clinton and Chrétien Years." Canadian Journal of Political Science 33: 7-36.

Boase, J.P. 2003. “Is There Hope for Canadian Health Care?” Canadian Public Administration 46: 397-408.

Boychuk, G.W. 2008. “National Health Insurance in the United States and Canada: Race, Territory, and the Roots of Difference." Washington, DC: Georgetown University Press. 
Cameron, D.R. and J.D. Krikorian. 2002."The Study of Federalism1960-99: A Content Review of Several Leading Canadian Academic Journals." Canadian Public Administration 45: 328-63.

Canadian Health Coalition. Romanow Commission Research Papers. Retrieved March 19, 2011. <http://healthcoalition.ca/romanow-papers $>$.

Church, J. and N. Smith. 2006. "Health Reform and Privatization in Alberta." Canadian Public Administration 49: 486-505.

Davidson, A. 2004. “Dynamics without Change: Continuity of Canadian Health Policy." Canadian Public Administration 47: 251-79.

Forest, P.G, G. Marchildon and T.A. McIntosh. 2004. Romanow Papers. Toronto: University of Toronto Press.

Fulton, M.J. and W.T. Stanbury. 1985. "Comparative Lobbying Strategies in Influencing Health Care Policy." Canadian Public Administration 28: 269-300.

Gelber, S.M. 1966."The Path to Health Insurance." Canadian Public Administration 9: 211-20.

Geva-May, I. and A. Maslove. 2000.“What Prompts Health Care Policy Change? On Political Power Contests and Reform of Health Care Systems (The Case of Canada and Israel)." Journal of Health Politics, Policy and Law 25: 717-41.

Gray, K.G. 1946. “Canadian and American Health Insurance Plans." Canadian Journal of Economics and Political Science 12: 505-9.

Hale, G. 2002. The Politics of Taxation in Canada. Peterborough: Broadview Press.

Ham, L. 2001. "Consulting on Health Policy in Canada," In Citizens as Partners: Information, Consultation and Public Participation in Policy-Making (pp. 85-105). Paris: Organization of Economic Cooperation and Development (OECD).

Howlett, M. 2002.“Do Networks Matter? Linking Policy Network Structure to Policy Outcomes: Evidence from Four Canadian Policy Sectors 1990-2000." Canadian Journal of Political Science 35: 235-67.

Howlett, M. and M. Ramesh. 2003. Studying Public Policy: Policy Cycles and Policy Subsystems. Toronto: Oxford University Press.

Kelly, J.B. 2001."Reconciling Charter Rights and Federalism During Review of the Charter of Rights and Freedoms: The Supreme Court of Canada and the Centralization Thesis, 1982 to 1999." Canadian Journal of Political Science 34: 321-55.

Lazar, H., F. St-Hilaire and J.F. Tremblay. 2004. “Federal Health Care Funding: Towards a New Fiscal Pact." In H. Lazar and F. St-Hilaire, Money, Politics and Health Care (pp. 189-250). Montreal: Institute for Research in Public Policy.

Lemieux, V. 1989.“La Commission Rochon et la réalisation des politiques publiques." Canadian Public Administration 32: 261-73.

Lightman, E. 2003. Social Policy in Canada. Toronto: Oxford University Press.

Maioni, A. 1998. "Les Politiques de santé au Canada et aux États-Unis: des trajectoires irréconciliables?” Revue internationale de politique comparée 5: 343-62.

Maioni, A. 2002. "Federalism and Health Care in Canada." In K.G. Banting and S. Corbett, Health Policy and Federalism: A Comparative Perspective on Multi-Level Governance (pp. 173-99). Montreal: McGill-Queen's University Press.

Marchildon, G.P. 2006. Health Systems in Transition: Canada. Toronto: University of Toronto Press.

Mhatre, S.L. and R.B. Deber. 1992."From Equal Access to Health Care to Equitable Access to Health: A Review of Canadian Provincial Health Commissions and Reports." International Journal of Health Services 22: 645-68.

O'Neill, M.A. 1996. "Health as an Irreversible Part of the Welfare State: Canadian Government Policy Under the Tories." International Journal of Health Services 26: 547-59.

O'Neill, M.A. 1997 (Spring). “Stepping Forward, Stepping Back? Health Care, the Federal Government and the New Canada Health and Social Transfer." International Journal of Canadian Studies 15: 169-85.

Orsini, M. 2002."The Politics of Naming, Blaming and Claiming: HIV, Hepatitis C and the Emergence of Blood Activism in Canada." Canadian Journal of Political Science 35: 475-98. 


\section{Canadian Political Science and Medicare}

Philipon, D.J. and S.A. Wasylyshyn. 1996. "Health-Care Reform in Alberta." Canadian Public Administration 39: 70-84.

Prince, M.J. 2001. “Canadian Federalism and Disability Policy Making." Canadian Journal of Political Science 34: 791-817.

Redden, C.J. 2002 (March). “Health Care as Citizenship Development: Examining Social Rights and Entitlement.” Canadian Journal of Political Science 35(1): 103-25.

Rice, J.R. and M.J. Prince. 2000. Changing Politics of Canadian Social Policy. Toronto: University of Toronto Press. Rivest, F. 1984. “L'Assurance-maladie au Canada: les raisons de l'implication de l'état." Canadian Public Administration 27: 24-47.

Simeon, R. 2002. Political Science and Federalism: Seven Decades of Scholarly Engagement. Kingston, ON: Queen's University Institute of Intergovernmental Relations.

Sinclair, T.A. 1981. "Introduction." In The Politics, by Aristotle, translated by T.A. Sinclair. New York: Penguin Books.

Soroka, S.N. 2007. Canadian Perceptions of the Health Care System: A Report to the Health Council of Canada. Toronto: Health Council of Canada.

St-Hilaire, F. and H. Lazar. 2003 (February). "He Said, She Said: The Debate on Vertical Fiscal Imbalance and Federal Health-Care Funding," Policy Options 24(2): 60-67.

Swartz, D. 1993. “The Politics of Reform: Public Health Insurance in Canada.” International Journal of Health Services 23: 219-38.

Taylor, M.G. 1960."The Role of the Medical Profession in the Formulation and Execution of Public Policy." Canadian Journal of Economics and Political Science 26: 108-27.

Taylor, M.G. 1972."Quebec Medicare: Policy Formulation in Conflict and Crisis." Canadian Public Administration 15: 211-50.

Taylor, M.G. 2009. Health Insurance and Canadian Public Policy: The Seven Decisions that Created the Canadian Health Insurance System. Montreal: McGill-Queen's University Press.

Tuohy, C.J. 1976. “Private Government, Property, and Professionalism." Canadian Journal of Political Science 9: 668-81.

Tuohy, C.J. 1988. "Medicine and the State in Canada: The Extra-Billing Issue in Perspective." Canadian Journal of Political Science 21: 267-96.

Wilson, D.M. 2001. "Public and Private Health-Care Systems: What the Literature Says." Canadian Public Administration 44: 204-31. 